\title{
SOSIALISASI URBAN FARMING DI KELURAHAN TAFURE TERNATE DENGAN POLA TANAM MIXED FARMING SAAT PANDEMI DAN NEW NORMAL
}

\author{
Rima Melati ${ }^{1}$, Suratman Sudjud ${ }^{2}$, Sarni $^{3}$ \\ ${ }^{1,2,3}$ Fakultas Pertanian Universitas Khairun
}

email rima_tafure@yahoo.com,suratmansudjud@gmail.com,sarniriyadi@yahoo.com

\begin{abstract}
ABSTRAK
Pandemi Covid-19 yang melanda dunia sangat berdampak pada sektor pertanian, terutama produksi dan distribusi bahan pangan. Daerah yang sumber pendapatan di sektor jasa seperti Kota Ternate sangat tergantung pada stok pangan dari pulau lain yang selama ini terjadi. Hal ini berdampak buruk pada ketersediaan bahan pangan karena daerah penyuplai mengalami pengurangan dan akses transportasi yang terhambat. Solusi mendasar adalah petani di daerah perkotaan harus memenuhi kebutuhan pangan keluarga sendiri. Sosialisasi tentang urban farming serta pemberian benih hortikultara pada petani partisipan termasuk langkah awal untuk memberikan motivasi, agar lahan yang kosong maupun pekarangan dapat ditanam dengan berbagai tanaman. Sosialisasi dilakukan dengan metode observasi, diskusi bersama dan pemberian stimulus berupa benih hortikultura. Dampak dari kegiatan sosialisasi adalah petani partisipan memahami urban farming dengan pola tanam mixed farming. Pasca sosialisasi $80 \%$ petani partisipan membersihkan lahan kosong dan $70 \%$ telah menanam sayur dari benih yang diberikan. Keberlanjutan dari kegiatan petani yaitu memelihara tanaman hingga panen dan petani masih membutuhkan penyuluhan tentang pemeliharaan tanaman yang beragam dalam suatu areal tanam.
\end{abstract}

Kata Kunci: Sosialisasi, Urban Farming, Mixed Farming, Pandemi, Covid-19.

\begin{abstract}
The Covid-19 pandemic in the world have a major influence in the agricultural sector, especially the production and distribution of foods. The source of income in the services sector as Ternate City very dependent on food stocks from other islands. This has a negative impact on the availability of foodstuffs because the supply areas experience a reduction and access to transportation is hampered. The basic solution is that farmers in urban areas must fulfill their own family food needs. Socialization about urban farming and the provision of horticultural seeds to participating farmers is a first step to provide motivation, so that empty land and yards can be planted with various plants. The socialization was carried out by the method of observation, joint discussion and providing a stimulus in the form of horticultural seeds. The impact of the socialization activities is that participating farmers understand urban farming using mixed farming patterns. After the socialization, $80 \%$ of the participating farmers cleared empty land and 70\% had planted vegetables from the seeds provided. The sustainability of the farmer's activities, namely maintaining plants until harvesting and farmers still need counseling on the maintenance of various plants in a planted area
\end{abstract}

Keywords: Socialization, Urban Farming, Mixed Farming, Pandemic, Covid-19. 


\section{PENDAHULUAN}

Krisis kesehatan yang melanda dunia saat ini berdampak besar terhadap semua sektor. Sejak diumumkan oleh media Indonesia pada bulan Maret 2020 bahwa Corona Virus atau biasa disebut Covid19 terjangkit Indonesia. Dalam kurun waktu yang sangat singkat Pemerintah Indonesia mengumumkan bahwa sebaran virus tersebut merupakan bencana nasional. Pandemi berdampak pada perekonomian, pendidikan, dan perhubungan. Sektor perekonomian termasuk sektor fatal yang perlu menjadi perhatian tertutama produksi dan distribusi bahan pangan. Stok pangan Indonesia masih tersedia dalam kurun waktu beberapa bulan kedepan, namun perlu antisipasi ketika siklus sebaran virus membutuhkan waktu yang masih panjang. Setiap daerah menjaga stok pangan selalu terpenuhi, sehingga akan menganggu distribusi pangan di daerah lain yang dalam kondisi normal, penyediaannya tergantung dari pasokan provinsi lain. Urban farming berkaitan dengan proses budidaya dan distribusi pangan di areal perkotaan yang terdiri dari komoditi perternakan, perikanan, wana tani dan hortikultura (Aslichati et al., 2018).

Kota Ternate termasuk daerah yang sumber pendapatan terbesar adalah jasa. Pertanian termasuk sumber pendapatan masyarakat nomor dua terutama di perkebunan. Oleh karena itu penyediaan bahan pokok seperti beras, sayur, ayam, telur berasal dari daerah lain seperti Jawa, Sulawesi Selatan, Sulawesi Utara dan Pulau Halmahera. Ketergantungan suplai dari daerah lain menjadi permasalahan saat pandemi. Oleh karena itu untuk menjaga kestabilan stok pangan, perlu suatu terobosan dalam penyedian pangan untuk keperluan keluarga. Beberapa masyarakat di daerah perkotaan seperti di Kelurahan Tafure memiliki hobi berkebun. Kebun yang dikelola sejak lama dan status lahan yang digunakan adalah lahan milik orang lain. Lahan tersebut adalah lahan milik pemerintah maupun perorangan yang dipinjamkan untuk kegiatan menanam tanaman bulanan. Komoditi yang diusahakan seperti singkong, ubi jalar, pisang dan jagung. Praktik berkebun ini disebut urban farming sekaligus pemanfaatan pekarangan di areal perkotaan dengan menanam berbagai jenis tanaman yang bertujuan untuk memenuhi kebutuhan sendiri (Wachdijono et al., 2019). Target kegiatan ini adalah memberikan sosialisasi dan motivasi kepada masyarakat memanfaatkan pekarangan dengan sistem mixed farming. Kebun yang selama ini diusahakan adalah sistem monokultur singkong, dianjurkan untuk merubah sistem penanaman dengan cara mixed farming. Mixed farming adalah sistem pertanaman campuran yang terdiri dari beberapa komoditi dalam suatu luasan tertentu. Sasaran kegiatan adalah masyarakat dapat memenuhi kebutuhan pangan sendiri, seperti ubi-ubian, sayur dan bumbu dapur. Target lain adalah mengurangi pengeluaran keluarga dan menjaga stok pangan keluarga di saat pandemi dan new normal dengan mengoptimalkan lahan kosong, 
sebagaimana dijelaskan bahwa lahan kosong dioptimalkan dengan upaya pemenuhan pangan keseharian (Muttaqin et al., 2019).

Sosialisasi urban farming ini tentunya bertujuan untuk mengarahkan sistem tanam mixed farming. Oleh karena itu pemberian benih hortikultura kepada masyarakat target bertujuan untuk memberikan stimulus agar komoditi yang diusahakan beragam. Selain tanaman penghasil karbohidrat, masyarakat juga menanam dan mengkonsumsi tanaman sayuran dan tanaman bumbu dapur. Urban farming sudah banyak dilakukan di daerah perkotaan seperti di Surabaya, Cirebon, Semarang (Junainah et al., 2016 ; Wachdijono et al., 2019 ;Luthan et al., 2019).

Kondisi pandemi Covid-19 dan memasuki kondisi normal baru serta mengantisipasi distribusi stok pangan yang terhambat, maka sosialisasi urban farming di daerah perkotaan perlu dilakukan. Fakta menunjukkan bahwa beberapa masyarakat senang berkebun di pekarangan ataupun memanfaatkan lahan kosong dengan menanam singkong di Kelurahan Tafure, menjadi motivasi dalam melaksanakan pengabdian masyarakat dengan memberikan stimulus benih hortikultura sebagai tanaman sela di antara tanaman singkong. Berdasarkan kondisi tersebut maka perlu dilaksanakan kegiatan pengabdian tentang "Sosialisasi Urban Farming pada Petani Kelurahan Tafure Ternate tentang Pola Tanam Mixed Farming disaat Pandemi dan New Normal". Kegiatan ini bertujuan agar petani perkotaan dapat memanfaatkan lahan kosong dengan menanam berbagai tanaman dalam satu lahan atau pekarangan, sehingga dapat memenuhi pangan keluarga di saat kondisi pandemi Covid-19.

\section{METODE}

Pelaksanakan kegiatan berlokasi di Kelurahan Tafure Kecamatan Ternate Utara. Kegiatan sosialisasi dan penyerahan benih dilakukan selama tiga hari yakni tanggal 21 - 23 Juni 2020. Partisipan dalam kegiatan ini adalah petani perkotaan yang lokasi berkebunnya berbeda-beda. Partisipan adalah ibu-ibu rumah tangga dan bapak-bapak yang hobi berkebun yang berjumlah 10 orang. Petani-petani tersebut sudah berkebun dengan menanam singkong secara monokutur. Pekarangan yang dijadikan aktivitas berkebun adalah pekarangan rumah dan lahan kosong milik pemerintah maupun perorangan yang status lahan adalah lahan pinjam.

Bahan yang diperlukan dalam kegiatan ini adalah benih, plastik untuk wadah benih, materi sosialisasi dan spanduk. Alat yang diperlukan adalah alat tulis menulis, kamera dan peralatan berkebun milik partisipan. 
Metode pelaksanaan kegiatan adalah diskusi bersama, observasi dan pemberian benih secara langsung. Observasi dilakukan selama dua hari yang dibantu oleh dua orang mahasiswa Program Studi Agroteknologi. Observasi hari pertama dilakukan di lokasi kegiatan, terutama mengidentifikasi jenis komoditi yang diusahakan petani partisipan dan kondisi tanaman. Observasi hari kedua dilakukan di pekarangan rumah salah satu warga yang menanam tanaman campuran. Kemudian koordinasi kegiatan di ketua rukun tetangga dimana lokasi kegiatan dilaksanakan. Metode observasi adalah kegiatan pendahuluan dalam membangun komunikasi dan mendapatkan informasi awal tentang lokasi kegiatan (Kusumastuti dan Darsono, 2019). Metode diskusi bersama dilakukan di areal kebun petani partisipan yang ada dalam suatu lokasi. Setelah diskusi dilanjutkan dengan penyerahan benih hortikultura. Pemberian benih hortikultura ini adalah kerjasama antara anggota Perhimpunan Agronomi Indonesia Komisariat Daerah Maluku Utara yang secara simbolis diserahkan ke perwakilan petani, kemudian benih tersebut dibagikan ke petani lain. Diskusi berlangsung selama 3-4 jam sekaligus observasi beberapa tanaman singkong yang terserang penyakit. Hasil observasi penyakit juga menjadi bahan diskusi dan koleksi data.

Pelaksanaan kegiatan dibagi sesuai dengan tugas dan masing-masing tim. Mahasiswa bertugas melakukan observasi lokasi dan berkomunkasi dengan para petani sekaligus menyampaikan kegiatan kepada aparat kelurahan. Diskusi bersama, observasi di lahan, penyerahan benih dilakukan oleh tim pelaksana kegiatan. Diskusi bersama bertajuk pola tanam mixed farming dengan tanaman hortikultura.

\section{PEMBAHASAN}

\section{Pelaksanaan Observasi Kebun}

Sosialisasi dan penyerahan benih dilakukan oleh tim bertempat di kebun. Kebun tersebut adalah kebun bersama yang dikelola oleh 10 partisipan. Kebun berada di lokasi sekitar areal perumahan dan sekolah. Ada 3 lokasi kebun yang terpisah tetapi berdekatan antar kebun yang satu dengan kebun lainnya. Tanah yang masih kosong dikelola oleh warga yang berdomisili di sekitar lahan kosong tersebut. Kebun tersebut telah lama dikelola, namun yang ditanam adalah tanaman singkong monokultur. Masih ada lahan yang kosong yang hanya ditumbuhi alang-alang (Gambar 1). Luas lahan garapan masing masing partisipan bervariasi antara $45 \mathrm{~m}^{2}-100 \mathrm{~m}^{2}$. Singkong yang ditanami adalah singkong lokal dan yang terkenal adalah singkong yang dinamakan "Kasbi Jame Jame”.

Lokasi kebun yang lain adalah lahan kosong yang digarap oleh partisipan yang berada di dekat pantai di RT 07 Kelurahan Tafure. Pemanfaatan lahan kosong ini berdasarkan kesepakatan bersama 
antara pemilik lahan dengan penggarap. Luas lahan sekitar $50 \mathrm{~m}^{2}$ dengan menanam tanaman singkong dan pepaya yang dijadikan sebagai tanaman pinggiran. Penyuluhan pemanfaatan lahan kosong kepada warga dapat menambah pengetahuan dan ketrampilan masyarakat (Radilla et al., 2020).

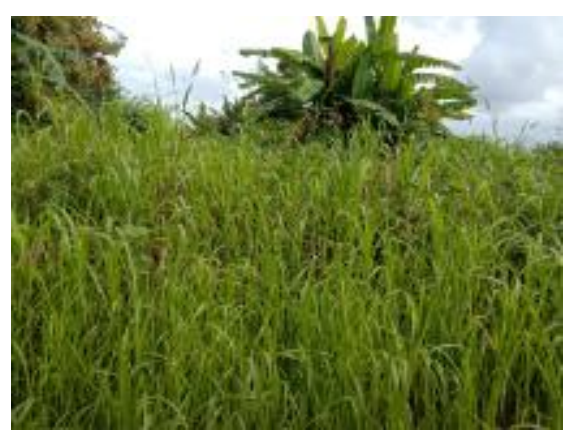

Gambar 1. Lahan yang belum dimanfaatkan

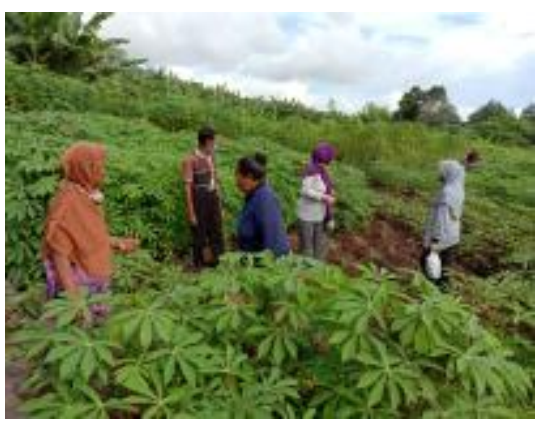

Gambar 2. Lahan yang sudah ditanami Singkong

\section{Pelaksanaan Sosialisasi Urban Farming dan Penyerahan Benih Hortikultura}

Pelaksanaan sosialisasi dan pengenal urban farming dilakukan di kebun. Penyampaian informasi tentang petani perkotaan dengan cara diskusi terbuka. Urban farming lebih ditekankan pada keragaman jenis komoditi yang ditanam. Selain itu dijelaskan juga tentang pengaturan tanam. Umumnya petani partisipan menanam dengan sistem monokultur singkong. Dengan pengabdian ini tentunya petani lebih memahami dan menerapkan sistem tanam tumpangsari atau multiple croping pada sebidang lahan garapannya. Urban farming ini bertujuan untuk memenuhi pangan keluarga, terutama singkong dan sayur dan bumbu dapur. Keanekaragaman jenis tanaman dapat memodifikasi ragam menu keluarga. Oleh karena itu, sosialisasi tidaklah cukup bagi petani. Pemberian benih hortikultura pada petani partisipan bertujuan untuk memberikan stimulus agar petani dapat menanam beraneka ragam pangan di kebun mereka. Selain itu lahan-lahan yang produktif dapat dimanfaatkan. Urban farming juga telah diterapkan di beberapa daerah di Sukolilo Surabaya dari tahun 2009 (Junainahet al., 2019).

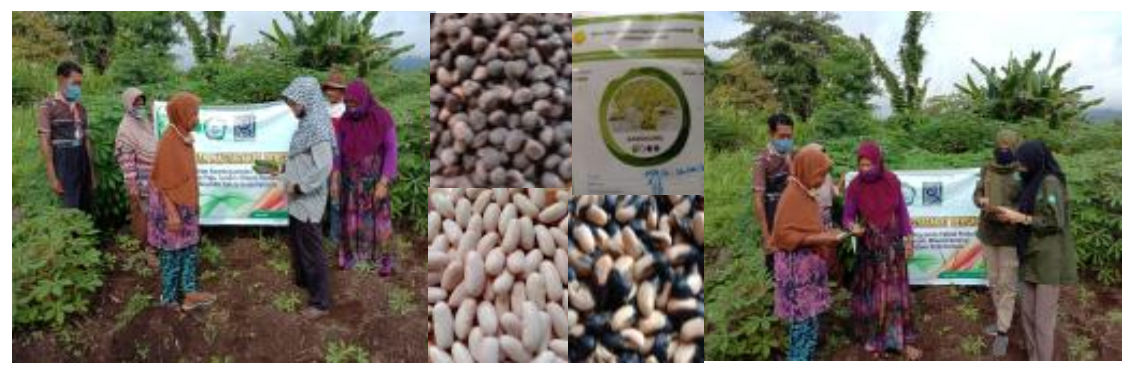

Gambar 3. Penyerahan Benih Sayur kepada Petani

Sosialisasi dengan cara diskusi bersama petani partisipan lebih efektif dan komunikatif. Proses diskusi lebih banyak informasi yang diperoleh terutama persoalan teknis budidaya. Semua petani 
partisipan memahami sosialisasi dan maksud sosialisasi tentang topik diskusi. Selain itu dapat menjadwalkan lanjutan pekerjaan yang disepakati bersama. Beberapa pendekatan transfer informasi juga telah dilakukan pada kegiatan serupa dan menggunakan istilah rembug warga. Sebagaimana yang dilakukan oleh Sugiarso et al. (2017) yang melaksanakan kegiatan pemanfaatan pekarangan untuk konservasi dan agribisnis.

\section{Kendala yang Dihadapi}

Pelaksanaan kegiatan pengabdian di lokasi sasaran pada kondisi pandemi mengalami beberapa kendala. Kendala tersebut bersifat teknik, karena mengurangi jumlah pertemuan dan jaga jarak. Pertemuan rutin dengan petani partisipanpun dikurangi. Kunjungan ke kebun pada waktu-waktu tertentu saja. Kunjungan dilakuakan pada saat pembersihan lahan dan fase pertumbuhan tanaman.

\section{Dampak dan Upaya Keberlanjutan}

Sosialisasi dan penyerahan benih dilanjutkan dengan kegiatan pembersihan lahan dan penanaman benih-benih yang telah diperoleh partisipan. Motivasi petani mengelola lahan kosong dengan tanaman hortikultura yang berasal dari benih yang diberikan. Hal ini merupakan dampak dan upaya keberlanjutan dari kegiatan pengabdian ini. Petani telah memahami sosialisasi urban farming dengan tujuan memenuhi kebutuhan pangan keluarga. Menanam tanaman hortikultura seperti sayur kacang panjang, timun, cabe, labu, bayam, kangkung di pekarangan rumah maupun di lahan yang baru digarap, penanaman tumpang sari diantara tanaman singkong adalah dampak dari kegiatan sosialisasi. Petani juga diharapkan memanfaatan lahan pekarangan dengan menggunakan pot atau polibag. Tanaman tersebut bertujuan untuk konsumsi rumah tangga seperti cabai, bayam, kangkung, bahkan sayuran menjalar seperti timun, gambas dan kacang panjang. Kegiatan pengabdian ini berdampak positif sebagaimana yang dilakukan di Kelurahan Limau Manih Kota Padang dengan menanam cabai dengan pot (Warnita dan Aisman, 2017). Persentasi aktivitas petani partisipan setelah mengikuti sosialisasi disajikan pada Tabel 1.

Observasi tim pengabdian dilakukan untuk melihat secara langsung aktivitas petani partisipan dalam menerapkan urban farming dengan pola mixed farming. Hasil observasi menunjukkan bahwa karakteristik urban farming terdiri dari dua tipe yang dilakukan oleh petani partisipan. Urban farming dengan karakter ruang terbuka dan pekarangan rumah. Karakteristik urban farming yang diterapkan sama dengan penerapan urban farming di Kampung Donorejo Kelurahan Kapasan Surabaya dengan sistem vertikultur (Nur'aini dan Krisdianto, 2017). Kunjung lapang dan observasi dilakukan tiga kali 
pasca sosialisasi yakni pembersihan lahan, awal pertumbuhan dan pertumbuhan vegetatif. Saat kunjung lapang disertai dengan diskusi bersama, terutama membahas tentang kendala-kendala teknis yang dihadapi saat penanaman.

Tabel 1. Persentasi Aktivitas Petani

\begin{tabular}{ll}
\hline No $\quad$ Aktivitas Pasca Sosialisasi & Dokumentasi Kegiatan \\
\hline $\begin{array}{l}80 \% \text { petani partisipan } \\
\text { membersihkan lahan dan } \\
\text { pekarangan }\end{array}$ & \\
70\% petani telah menanam & \\
\hline 3. & \\
tanaman hortikultura yang telah \\
memasuki fase vegetatif \\
$\begin{array}{l}\text { Kunjung lapang dan observasi } \\
\text { tanaman hortikultura fase vegetatif } \\
\text { oleh tim pengabdian }\end{array}$
\end{tabular}

\section{SIMPULAN}

Sosialisasi tentang urban farming dengan sistem mixed farming telah dipahami oleh petani partisipan di Kelurahan Tafure. Sosialisasi tersebut ditindaklanjuti oleh petani dengan membersihkan areal pekarangan maupun kebun dengan menanam berbagai jenis komoditi untuk kebutuhan keluarga. Benih hortikultura yang telah diberikan telah dimanfaatkan petani dengan menanam tanaman sayuran di kebun maupun pekarangan. Karakteristik urban farming yang diterapkan petani partisipan adalah urban farming pekarangan dan ruang terbuka. Kelanjutan dari kegiatan ini yang diharapkan adalah memelihara tanaman yang sedang tumbuh sampai panen, sehingga dapat dimanfaatkan untuk kebutuhan keluarga di tengah pandemi Covid-19 dan tatanan hidup baru, serta berlanjut pada musim tanam berikutnya. Program 
pengabdian selanjutnya yang harus dilakukan adalah penyuluhan tentang pemeliharaan tanaman pada areal tanam dengan sistem mixed farming.

\section{UCAPAN TERIMAKASIH}

Ucapan terima kasih kepada Ketua RT 007 dan 008 yang telah memberikan support atas keberlangsungan kegiatan. Pengahargaan dan ucapan terima kasih kepada Perhimpunan Agronomi Indonesia Komisariat Maluku Utara (PERAGI-MALUT) atas pastisipasinya menyumbangkan benih sayuran dalam kegiatan ini.

\section{DAFTAR PUSTAKA}

Aslichati, Lilik; Silawati, Tutisiana; Hartari, Ariyanti; Priono, M. 2018. Pengembangan Urban Farming Di Rw 07 Bukit Indah. Proseeding Seminar Nasional Pengabdian Kepada Masyarakat Universitas Terbuka, 1(1), 245-250.

District, H., City, C., Wahyuni, S., Trisnaningsih, U. (n.d.). Penerapan Urban Farming “Vertikultur ” untuk Menambah Pendapatan Rumah Tangga di Kelurahan Kalijaga Kecamatan Harjamukti Kota Cirebon. 374-381.

Iskandar, J., Iskandar, B. Su. 2016. Etnoekologi dan Pengelolaan Agroekosistem oleh Penduduk Desa Karangwangi Kecamatan Cidaun, Cianjur Selatan Jawa Barat. Jurnal Biodjati, 1(1), 1-12.

Junainah, W., Kanto, S., Soenyono. 2016. Program Urban Farming Sebagai Model Penanggulangan Kemiskinan Masyarakat Perkotaan. Wacana, 19(3), 148-156.

Kusumastuti, C. T., Darsono, D. 2019. Pemberdayaan Pkk Dengan Pemanfaatan Tanah Pekarangan Untuk Mendukung Perwujudan Hatinya Pkk. Jurnal Berdaya Mandiri, 1 (1), 19-24.

Luthan, P. L. A., Nikman, Y., Hasibuan, H. N., Malau, J. P. A. 2019. Pelatihan Urban Farming Sebagai Solusi Ruang Terbuka Hijau Di Lorong Sidodadi Medan Helvetia. Jurnal Pengabdian Kepada Masyarakat, 25(1), 1. https://doi.org/10.24114/jpkm.v25i1.13933

Muttaqin, Z., silvya Sari, D., Purbasari, R. 2019. Pemanfaatan Lahan Kosong: Mengupayakan Ketahanan Pangan Global Dalam Keseharian Masyarakat Lokal Di RW 12, Desa Sayang, Jatinangor, Sumedang. Prosiding Penelitian dan Pengabdian kepada Masyarakat, 5 (3), 237-250.

Nur'aini A.D., J. Krisdianto, 2017. Urban Farming dalam Kampung Vertikal sebagai Upaya Efisiensi Keterbatasan Lahan, Jurnal Sains dan Seni Pomits, 6 (2) : 2337-3520

Radilla, N., Budiman, A. S., Risdiyanto, I. 2020. Penyuluhan Pemanfaatan Lahan Kosong di Desa Rawabelut, Kecamatan Sukaresmi, Kabupaten Cianjur. Jurnal Pusat Inovasi Masyarakat (PIM), 2(3), 484-487.

Sugiarso, S., Riyadi, A., Rusmadi, R. 2018. Pemberdayaan Masyarakat Melalui Pemanfaatan Tanah Pekarangan (PTP) untuk Konservasi dan Wirausaha Agribisnis di Kelurahan Kedung Pane Kota Semarang. Dimas: Jurnal Pemikiran Agama Untuk Pemberdayaan, 17 (2), 343.

Wachdijono, W., Wahyuni, S., Trisnaningsih, U. 2019. Sosialisasi Urban Farming Melalui Budidaya 
Tanaman Sayuran Secara Vertikultur Dan Hidroponik Di Kelurahan Kalijaga, Kecamatan Harjamukti, Kota Cirebon. Qardhul Hasan: Media Pengabdian Kepada Masyarakat, 5 (2), 90.

Warnita, W., Aisman, A. 2017. Pemberdayaan Masyarakat Melalui Budidaya Tanaman Cabai Merah Dalam Pot. Logista-Jurnal Ilmiah Pengabdian kepada Masyarakat, 1 (2), 41-50. 